\title{
Oxidation Behavior and Surface Tension of Mg-1.2Ca Alloy with Ce Addition
}

\author{
Qin Lin, Ding Jian, Zhao Weimin, Fang Zheng \\ Hebei University of Technology, Tianjin 300132, China
}

\begin{abstract}
The effects of alloying element $\mathrm{Ce}$ on the oxidation behavior and the surface tension of $\mathrm{Mg}-1.2 \mathrm{Ca}$ alloy were investigated in order to further develop the burn resistant magnesium alloys. Results show that with the increase of Ce content from $0 \mathrm{wt} \%$ to 1.5 $\mathrm{wt} \%$, the ignition point of $\mathrm{Mg}-1.2 \mathrm{Ca}$ alloy increases rapidly while the surface tension declines. The ignition point of $\mathrm{Mg}-1.2 \mathrm{Ca}-1.2 \mathrm{Ce}$ alloy can reach $780{ }^{\circ} \mathrm{C}$. It can be melted in atmosphere without any protection method. The oxidation film of $\mathrm{Mg}-1.2 \mathrm{Ca}$ melt becomes smooth and dense with the increase of $\mathrm{Ce}$ addition, which can prevent magnesium alloys from further oxidation and burning. According to the test and analysis, the oxide film of $\mathrm{Mg}-1.2 \mathrm{Ca}-1.2 \mathrm{Ce}$ alloy consists of three layers, that is, loose $\mathrm{MgO}$ in the outer layer, $\mathrm{MgO}-\mathrm{CaO}$ composite oxide film in the middle layer and $\mathrm{MgO}-\mathrm{Ce}_{2} \mathrm{O}_{3}$ composite oxide film in the inner layer.
\end{abstract}

Key words: magnesium alloy; oxidation; surface tension; calcium; cerium

Magnesium alloys are widely used in aerospace, electronic technology and automotive industry due to their good properties such as low density, high specific strength and stiffness, as will as good processability. However, magnesium alloys are prone to oxidate or even burn as they have high chemical activity and loose oxide film. So fluxes or protective gas methods should be taken to prevent oxidation during melting and casting processes ${ }^{[1]}$. However, both of two methods would lead to many problems, such as inclusion, environmental pollution and complication of melting process and equipment. So it is necessary to investigate a better burn resistant method.

Alloying is an effective method to improve the burn resistant performance of magnesium alloys. Recently, the effect of rare earth (RE) on properties of magnesium alloys has been investigated. RE is usually used as addition element to enhance the oxidation resistance ${ }^{[2]}$. It was revealed that $\mathrm{Ce}$ content in the solid solution will influence the burn resistant performance of magnesium alloys together with other elements in the alloys, such as Ca. The interactive effect on the oxidation resistance is much more complicated than that of the single element in the solid solution. Sakamoto et al. ${ }^{[3]}$ studied the oxidation of $\mathrm{Mg}-\mathrm{Ca}$ alloy. The results indicated that the ignition temperature could increase by $250{ }^{\circ} \mathrm{C}$ after 5 $\mathrm{wt} \% \mathrm{Ca}$ was added into pure magnesium. They also found that the burn resistant performance was improved at the cost of the decrease of tensile properties, so the content of $\mathrm{Ca}$ should be controlled in about $1 \mathrm{wt} \%$ for the pure magnesium.

Surface tension is both a fundamental property and an important technological parameter to high temperature alloy ${ }^{[4]}$, which is related to the concentration of active element, the internal stress and the wettability. And above mentioned parameters have a great influence on the formation and the morphology of oxide film of magnesium alloys. However, the surface tension of the magnesium alloy melt was rarely studied. The structure of the oxide film on the molten alloy and its thermodynamic and kinetic mechanisms were far from being understood. In the present paper, the author also studied the oxidation behavior of magnesium alloys by means of surface tension testing.

\section{Experiment}

Received date: January 24, 2015

Foundation item: Natural Science Foundation of Heibei Province (E2010000121); Science and Technology Research of Hebei Province for Youth Found (2011182) Corresponding author: Ding Jian, Ph. D., Associate Professor, School of Materials Science and Engineering, Hebei University of Technology, Tianjin 300132, P. R. China, E-mail: djian@126.com 
$\mathrm{Mg}-1.2 \mathrm{Ca}-x \mathrm{Ce}$ alloys used in the present investigation was smelted from commercial pure $\mathrm{Mg}$ (99.95\%), $\mathrm{Mg}-29.7 \% \mathrm{Ca}$ and $\mathrm{Mg}-30.0 \% \mathrm{Ce}$ master alloys in an SG2-1.5-12 electric resistance furnace under the protection of $99.5 \mathrm{vol} \% \mathrm{CO}_{2}-$ $0.5 \mathrm{vol} \% \mathrm{SF}_{6}$ gases. The raw materials were first cut and mixed in a proper ratio, melted and then cast into mould, finally the ingots with composition of $\mathrm{Mg}-1.2 \mathrm{Ca}-x \mathrm{Ce}(x=0,0.3,0.6,0.9$, $1.2,1.5)$ were obtained.

The samples were taken from the central section of the ingots, and then they were machined to cylindrical shape with the dimension of $\Phi 12 \mathrm{~mm} \times 15 \mathrm{~mm}$ for testing ignition points. Upon testing the ignition points, the samples were continuously heated in the electric resistance furnace at a constant heating rate of $4{ }^{\circ} \mathrm{C} / \mathrm{min}$ until the ignition occurrance $^{[5]}$. And the temperature during heating was measured with a multi-channel data acquisition system (with an accuracy of $\pm 2{ }^{\circ} \mathrm{C}$ ). It is worthy mentioning that neither flux nor gas protection were used in this process. For each alloy, the ignition point was tested for three times and then the average value of ignition point was calculated.

The surface tension of molten $\mathrm{Mg}-1.2 \mathrm{Ca}-x \mathrm{Ce}$ alloys were measured at the temperature of $730{ }^{\circ} \mathrm{C}$ in open air using the maximum bubble pressure method (MBPM) ${ }^{[6]}$, as shown in Fig.1. The maximum bubble pressure method proposed by Simon $^{[7]}$ is based on the use of a single capillary immersed into the studied liquid. $\mathrm{Mg}-29.7 \% \mathrm{Ca}$ and $\mathrm{Mg}-30.0 \% \mathrm{Ce}$ interalloys were added after commercially pure $\mathrm{Mg}$ melted completely at the temperature of $730{ }^{\circ} \mathrm{C}$, removing the impurities of melt surface. The surface tension were tested after maintaining the melt at the temperature of $730^{\circ} \mathrm{C}$ for $15 \mathrm{~min}$.

The surface tension $\sigma$ can be calculated from the measured maximum capillary pressure $P$ and the known capillary radius $r$ by the Laplace equation ${ }^{[8]}$ :

$$
\sigma=\operatorname{Pr} / 2
$$

The measured capillary pressure $P$ can be expressed via the excess maximum pressure in the measuring system $P_{\mathrm{s}}=\rho_{1} \mathrm{~g} H_{\max }$, where $H_{\max }$ represent the maximum difference of liquid level between U-tube manometer, and $\rho_{1}$ is the density of liquid;

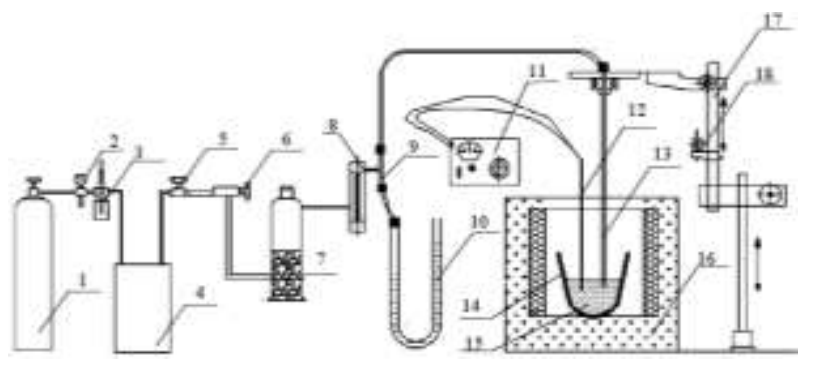

1-argon gas, 2-pressure reducer, 3-flowmeter, 4-pressure stabilizer, 5-needle valve, 6-fine needle valve, 7-drying bottle, 8-flowmeter, 9-three-limb tube, 10-U-tube, 11-temperature controller, 12-thermocouple, 13-capillary, 14-graphite crucible, 15-melt, 16-furnace, 17-bracket, 18-dialgage

Fig.1 MBPM surface tension testing schematic hydrostatic melt pressure $P_{\mathrm{h}}=\rho_{2} g h$, where $h$ is the immersion depth of the capillary into the melt, and $\rho_{2}$ is the density of melt. Hence the capillary pressure is given as follows:

$$
P=P_{\mathrm{s}}-P_{\mathrm{h}}
$$

Together with Eq.(1) we obtained:

$$
\sigma=\left(\rho_{1} H_{\max }-\rho 2 h\right) g r / 2
$$

The analyses of composition and microstructure of oxidation film were conducted by a Hitachi S4800 scanning electron microscope (SEM) equipped with energy dispersive spectrometer (EDS). The phase of oxidation film was examined by an X-ray diffraction (XRD) system (SmartLab, Rigaku) with $\mathrm{Cu} \mathrm{K} \alpha$ radiation.

\section{Results and Discussion}

\subsection{Ignition point testing}

A typical temperature-time curve of ignition point testing of pure magnesium is shown in Fig.2. The combustion heat of the samples is large enough to cause a steep rise in the temperature-time curve. The temperature-time curves display a rapid oscillation of rising in burning process and the first inflection point is defined as the ignition point of the sample in the present research ${ }^{[9]}$.

The results of the ignition point testing are shown in Fig.3. And the fitted curve is also drawn up in the figure, which complied with Gaussian function. As can be seen from the graph, the ignition point of $\mathrm{Mg}-1.2 \mathrm{Ca}$ increases rapidly when the content of $\mathrm{Ce}$ is in the range from $0 \mathrm{wt} \%$ to $1.2 \mathrm{wt} \%$. However, when the content of $\mathrm{Ce}$ is more than $1.2 \mathrm{wt} \%$, the ignition point is almost invariable. The average ignition point of $\mathrm{Mg}-1.2 \mathrm{Ca}-1.2 \mathrm{Ce}$ can reach $780{ }^{\circ} \mathrm{C}$, which is about $77^{\circ} \mathrm{C}$ higher than that of $\mathrm{Mg}-1.2 \mathrm{Ca}$. The data of ignition point of $\mathrm{Mg}-1.2 \mathrm{Ca}-x \mathrm{Ce}$ alloys can be fitted as the following equation:

$$
T=702.21+80.80 \exp \left[-2\left(\frac{x-1.39}{1.03}\right)^{2}\right]
$$

where, $T$ is the ignition point $\left({ }^{\circ} \mathrm{C}\right)$ and $x$ is analyzed content of $\mathrm{Ce}(\mathrm{wt} \%)$ in $\mathrm{Mg}-1.2 \mathrm{Ca}$.

\subsection{Oxide film analysis}

The oxide films of $\mathrm{Mg}-1.2 \mathrm{Ca}$ and $\mathrm{Mg}-1.2 \mathrm{Ca}-1.2 \mathrm{Ce}$ can be vividly seen in Fig.4. Both of them are cooled under natural condition from magnesium melt. As can be seen, the oxide

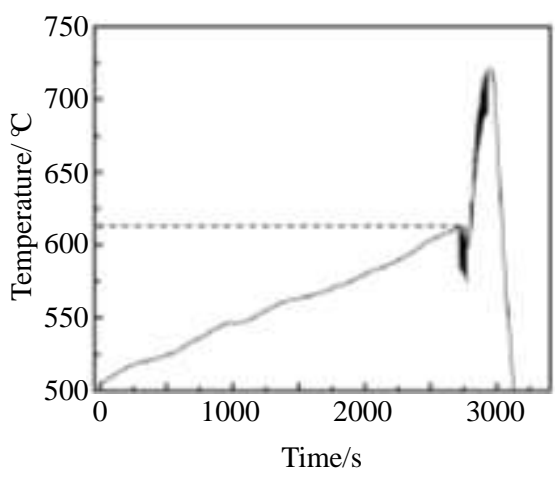

Fig.2 Typical ignition point test of pure magnesium 


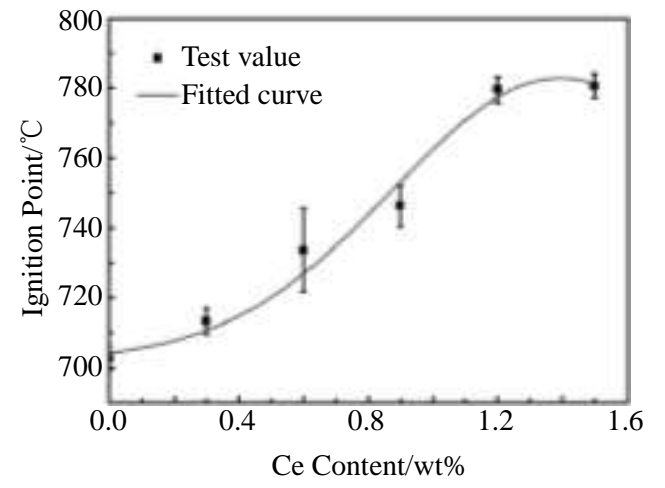

Fig.3 Effect of Ce content on the ignition point of $\mathrm{Mg}-1.2 \mathrm{Ca}$ alloy

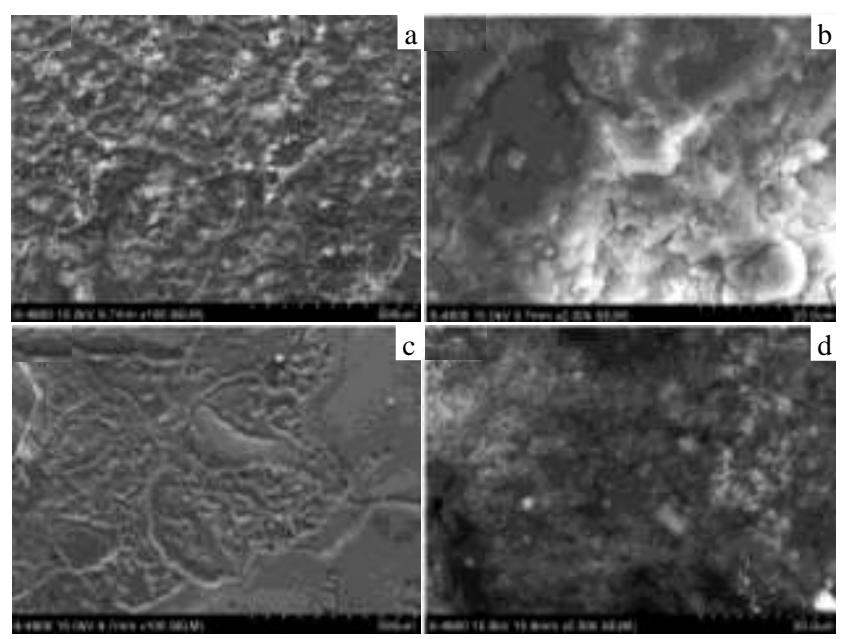

Fig.4 Oxide film morphologies of magnesium alloys with different Ce content: $(\mathrm{a}, \mathrm{b})$ the oxide film of $\mathrm{Mg}-1.2 \mathrm{Ca}$ and $(\mathrm{c}, \mathrm{d})$ the oxide film of $\mathrm{Mg}-1.2 \mathrm{Ca}-1.2 \mathrm{Ce}$

film of $\mathrm{Mg}-1.2 \mathrm{Ca}-1.2 \mathrm{Ce}$ is dense and bonds with the matrix very well. On the contrary, the oxide film of $\mathrm{Mg}-1.2 \mathrm{Ca}$ is thin and contains many micro-pores and cracks, which can well explain the difference of burn resistance performance between the two alloys.

The phase of $\mathrm{Mg}-1.2 \mathrm{Ca}-1.2 \mathrm{Ce}$ oxide film is composed of $\mathrm{Mg}, \mathrm{MgO}, \mathrm{CaO}$ and $\mathrm{Ce}_{2} \mathrm{O}_{3}$, which is confirmed by the XRD

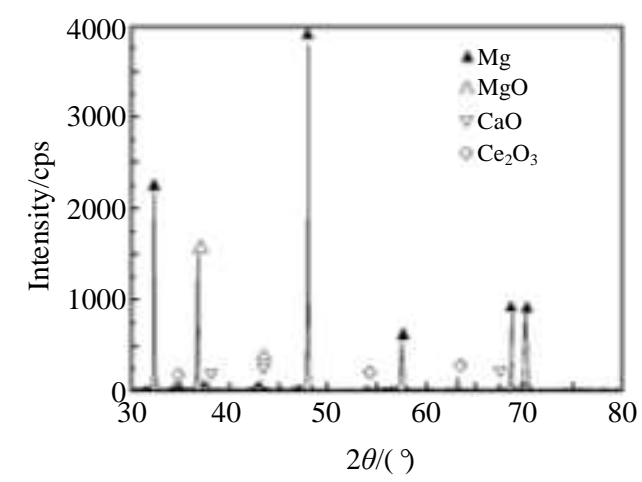

Fig.5 XRD pattern of Mg-1.2Ca-1.2Ce oxide film analysis in Fig.5. And the main reason of the improvement of the ignition point is that the oxide film tightness increases. The tightness is always expressed by $\mathrm{P}-\mathrm{B}$ ratio (ratio of the volume of the oxide to the consumed metal volume). When the $\mathrm{P}-\mathrm{B}$ ratio is larger than 1, the oxide film has the function to protect the matrix; while the $\mathrm{P}-\mathrm{B}$ ratio is smaller than 1 , the oxide film is loose. The $\mathrm{P}-\mathrm{B}$ ratio of pure magnesium equals to 0.81 for $\mathrm{MgO}^{[10]}$, and thus the surface oxide film cannot prevent the proliferation of oxygen and the oxidation of inner magnesium. However, the $\mathrm{P}-\mathrm{B}$ ratio of $\mathrm{Ce}_{2} \mathrm{O}_{3}$ is 1.16 , the addition of $\mathrm{Ce}_{2} \mathrm{O}_{3}$ in the oxide film can make it more compact.

The cross section morphology of $\mathrm{Mg}-1.2 \mathrm{Ca}-1.2 \mathrm{Ce}$ oxide film with thickness of $2 \sim 3 \mu \mathrm{m}$, is shown in Fig.6. When Ca and $\mathrm{Ce}$ are added to magnesium alloys, because the $\mathrm{P}-\mathrm{B}$ ratio is larger than 1, the filling of $\mathrm{Ca}$ and $\mathrm{Ce}$ oxide into the holes of magnesium results in the formation of a composite and compact coherent oxide film which can prevent the penetration of oxygen during heating. From the elements distribution, we can see that $\mathrm{Ca}$ and $\mathrm{Ce}$ are mainly located at the surface of magnesium melt. The oxide film can be divided into three layers. Due to the magnesium vapor pressure, the outer layer are mainly composed of loose $\mathrm{MgO}$. The middle layer and inner layer are mainly composed of $\mathrm{MgO}-\mathrm{CaO}$ and $\mathrm{MgO}-\mathrm{Ce}_{2} \mathrm{O}_{3}$ composite oxide film, respectively.

\subsection{Surface tension testing}

Rare earths are surface active elements, as they are prone to gather on melt surface, and this gathering phenomenon will greatly affect the oxide film of magnesium and its burn resistant performance. Surface tension is an important parameter to high temperature melt, which is a perfect way to reflect the value of $\mathrm{Ce}$ concentration. The surface tension of $\mathrm{Mg}-1.2 \mathrm{Ca}-x \mathrm{Ce}$ alloys were tested at $700{ }^{\circ} \mathrm{C}$, using MBP method. As can be seen in

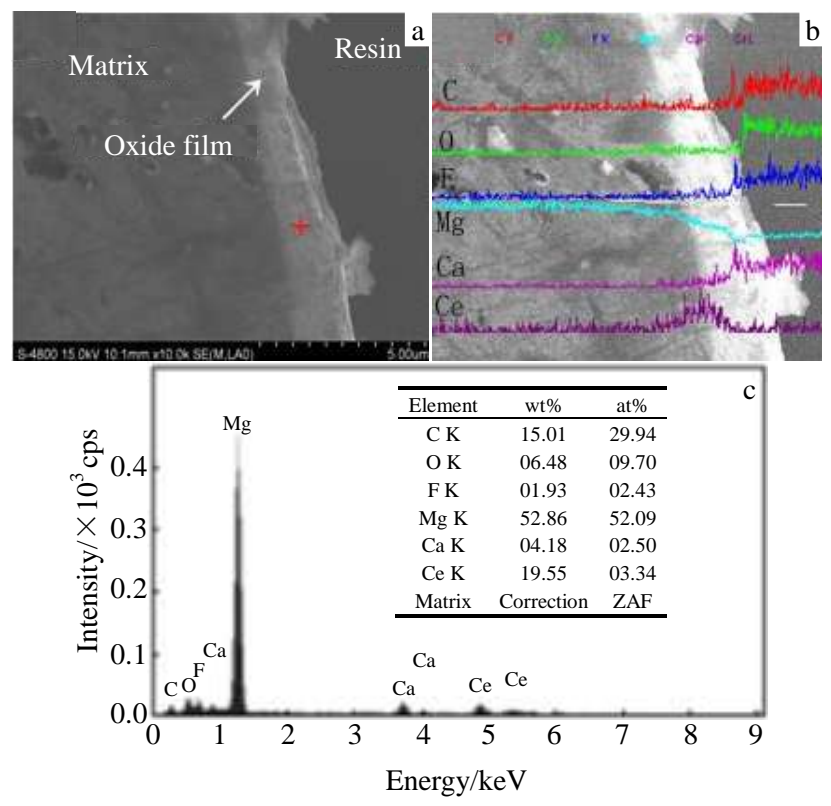

Fig.6 Morphology (a), EDS line analysis (b), and EDS spot analysis (c) for cross section oxide film of Mg-1.2Ca-1.2 Ce 
Fig.7, the surface tension of $\mathrm{Mg}-1.2 \mathrm{Ca}$ decreases rapidly with the increase of $\mathrm{Ce}$ content. The data of surface tension of $\mathrm{Mg}-1.2 \mathrm{Ca}-x \mathrm{Ce}$ alloys can be fitted as a parabola equation,

$$
\sigma=0.567-0.079 x+0.017 x^{2}
$$

where $\sigma$ represents surface tension, and $x$ is the content of Ce.

The relationship between surface tension and ignition point is illustrated in Fig.8. It can be seen that the ignition point increases with the decreasing of $\mathrm{Mg}-1.2 \mathrm{Ca}-x \mathrm{Ce}$ melt surface tension.

The gathering of $\mathrm{Ce}$ on the surface of magnesium alloy melt makes the surface tension reduce and greatly improves the burn resistance performance, resulting in forming a composite oxide film on melt surface. Internal stress is another factor to the burn resistant of magnesium alloys, which prompts the forming of wrinkle and crack. Hence, the internal stress should be controlled at a proper level. Ce is a surface active element, which can decline the surface tension and the internal stress. So this is another reason why oxidation resistant of $\mathrm{Mg}-1.2 \mathrm{Ca}$ is improved with $\mathrm{Ce}$ addition.

\subsection{Transformation in solid-state}

In order to understand the mechanism of burn resistance of magnesium alloy, the transformation of $\mathrm{Mg}-1.2 \mathrm{Ca}$ and $\mathrm{Mg}-1.2 \mathrm{Ca}-1.2 \mathrm{Ce}$ solid-state samples during continuous heating in the atmosphere were investigated. In the present study, the heating temperature was maintained at $730{ }^{\circ} \mathrm{C}$. And the evident changes of the samples were caught with the increasing of time. All the samples were polished before heating process.

Fig.9 shows the surface morphologies transformation of

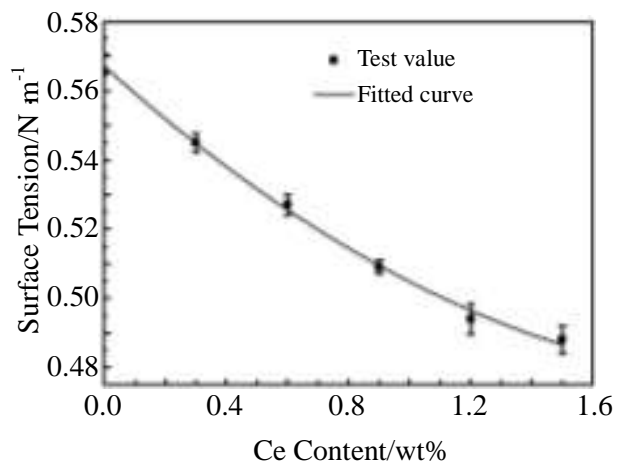

Fig.7 Effect of Ce content on the surface tension of $\mathrm{Mg}-1.2 \mathrm{Ca}$

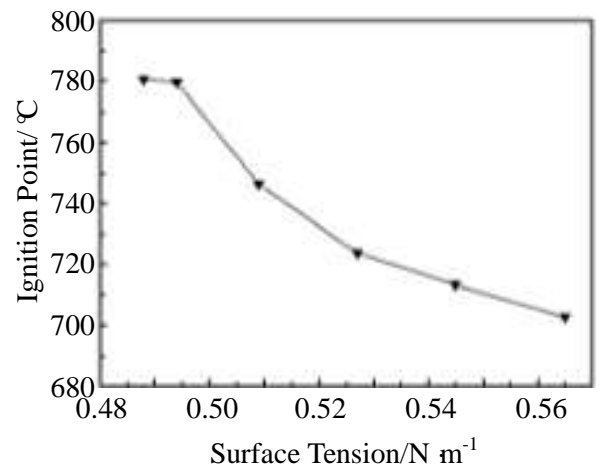

Fig.8 Relationship between surface tension and ignition point
$\mathrm{Mg}-1.2 \mathrm{Ca}$ solid-state at $730{ }^{\circ} \mathrm{C}$ for different heating time under atmosphere situation. After $10 \mathrm{~min}$ heating, a thin oxide film is generated on the surface of Mg-1.2Ca solid-state. From Fig.9a, Fig.9b, it can be seen that some wrinkles exist around the phase boundaries due to the unbalanced internal stress. When the time increases to $20 \mathrm{~min}$, the oxide film continues to grow, as seen in Fig.9c, Fig.9d). The increase of the thickness and the expansion of oxide film exacerbates the internal stress and the intensity of wrinkle. When the internal stress is large enough, the micropores or even obviously cracks may be produced at the edges of wrinkles. Owing to rapid transport rate of oxygen in external scale, the oxygen pressure at the scale/substrate interface is very high. Therefore, solid-state reactions among oxygen may occur, giving rise to complex oxides. The morphology of the oxide resembles some cauliflower, which can be seen in Fig.9e and Fig.9f.

The particularly high burn resistance of $\mathrm{Mg}-1.2 \mathrm{Ca}-1.2 \mathrm{Ce}$ can be again deduced from its solid-state transformation, as can be seen in Fig.10. Fig.10a, 10c and 10e images represent the morphologies of solid-state transformation, at $730{ }^{\circ} \mathrm{C}$ for different heating time. And the Fig.10b, 10d, and 10f are their high magnification images. The thin oxide film is formed after 10 min oxidation, which is very smooth. Then, many cracks appear on the surface of oxide film. The fracture mode of crack joint is ductile fracture which is full of dimples. With time and temperature increasing, some parts in the film collapse from the matrix. Fortunately, the surface of the magnesium alloy is packaged by a new dense oxide film, which completely isolates magnesium matrix from atmosphere.

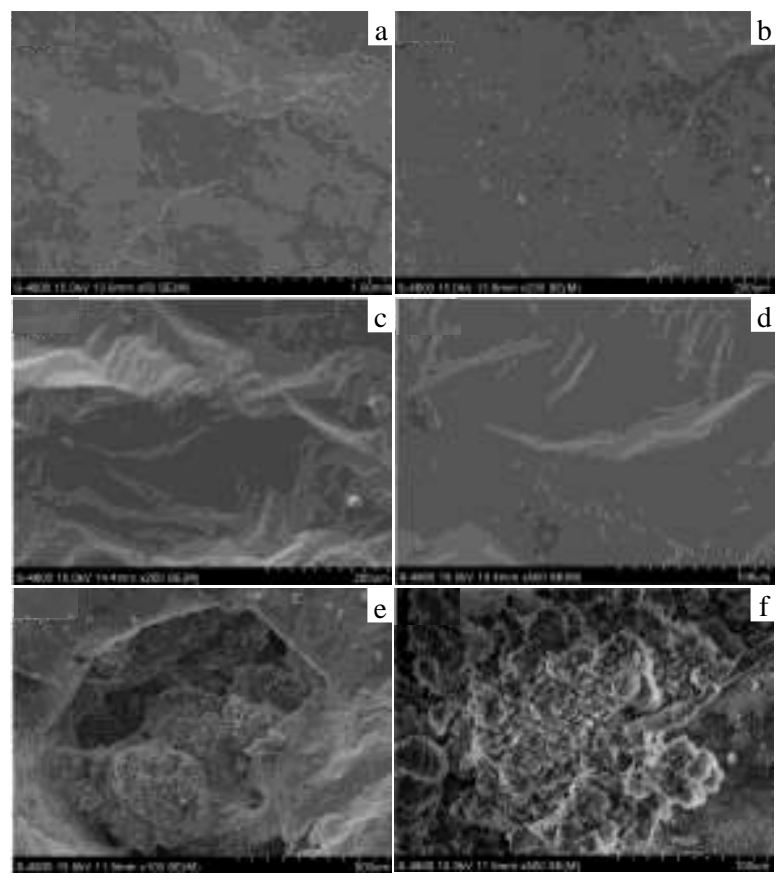

Fig.9 Morphologies transformation of $\mathrm{Mg}-1.2 \mathrm{Ca}$ solid-state at $730^{\circ} \mathrm{C}$ with different heating time: (a, b) $10 \mathrm{~min},(\mathrm{c}, \mathrm{d}) 20$ min, and (e, f) $40 \mathrm{~min}$ 


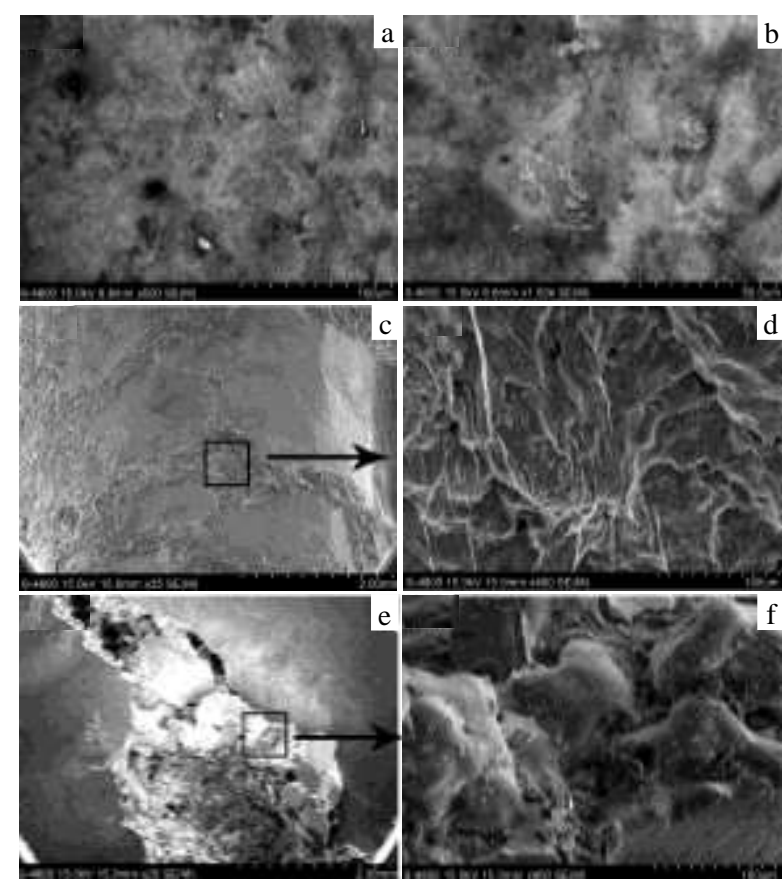

Fig.10 Morphologies transformation of $\mathrm{Mg}-1.2 \mathrm{Ca}-1.2 \mathrm{Ce}$ solid-state at $730{ }^{\circ} \mathrm{C}$ with different heating time: (a, b) $10 \mathrm{~min},(\mathrm{c}, \mathrm{d}) 20$ min, and (e, f) $40 \mathrm{~min}$

The effect of Ce on oxidation resistance in the present study should be attributed to the oxidation mechanism different from $\mathrm{Mg}-1.2 \mathrm{Ca}$ at $730{ }^{\circ} \mathrm{C}$. During the exposure at $730{ }^{\circ} \mathrm{C}$, both alloys exhibit different oxidation behaviors between the matrix and eutectic regions. This is associated with the difference of compositions in individual phases due to microsegregation during solidification. What is more, the huge difference in oxide film tightness is the most important reason for the appearance of the discrepancy of solid-state transformation between two alloys.

\section{Conclusions}

1) For the Mg-1.2Ca- $x \mathrm{Ce}$ magnesium alloys, the ignition point increases rapidly with increasing of Ce content from $0 \mathrm{wt} \%$ to $1.2 \mathrm{wt} \%$; however, the ignition point almost has no change when the Ce content is in the range from $1.2 \mathrm{wt} \%$ to $1.5 \mathrm{wt} \%$. The ignition point of $\mathrm{Mg}-1.2 \mathrm{Ca}-1.2 \mathrm{Ce}$ alloy can reach $780{ }^{\circ} \mathrm{C}$, which increases by $80^{\circ} \mathrm{C}$ compared with that of $\mathrm{Mg}-1.2 \mathrm{Ca}$ alloy.

2) The surface oxide film structure of magnesium alloy turns into the composite dense one from the porous by adding $\mathrm{Ce}$, which is composed of three layers: $\mathrm{MgO}$ outer layer, $\mathrm{MgO}-\mathrm{CaO}$ middle layer and $\mathrm{MgO}-\mathrm{Ce}_{2} \mathrm{O}_{3}$ inner layer.

3) The surface tension of $\mathrm{Mg}-1.2 \mathrm{Ca}$ inclines with the addition of $\mathrm{Ce}$. And the ignition point increases with the decreasing of surface tension of $\mathrm{Mg}-1.2 \mathrm{Ca}-x \mathrm{Ce}$ melt.

4) In the respect of the oxide film tightness, there exists a huge difference between $\mathrm{Mg}-1.2 \mathrm{Ca}$ and $\mathrm{Mg}-1.2 \mathrm{Ca}-x \mathrm{Ce}$. The ignition of $\mathrm{Mg}-1.2 \mathrm{Ca}$ is attributed to the wrinkles and cracks on oxide film. The $\mathrm{Mg}-1.2 \mathrm{Ca}-x \mathrm{Ce}$ have tight and dense oxide film which will package the alloys completely at high temperature resulting in isolating magnesium matrix from atmosphere, so the burn resistant performance of the alloys are improved greatly.

\section{References}

1 Cheng Suling, Yang Gencang, Fan Jianfeng et al. Transactions of Nonferrous Metals Society of China[J], 2009, 19: 299

2 Czerwinski F. Acta Materialia[J], 2002, 50: 2639

3 Sakamoto M, Akiyama S. Journal of Materials Science Letter[J], 1997, 16: 1048

4 Fainerman V B, Mys V D, Makiovski A V et al. Journal of Colloid and Interface Science [J], 2006, 304: 222

5 Ravi-Kumar N V, Blandin J J, Suéry M et al. Scripta Materialia[J], 2003, 49: 225

6 Fainerman V B, Miller R, Aksenenke E V et al. Advanced in Colloid and Interface Science [J], 2002, 96(1-3): 339

7 Simon M et al. Phys[J], 1851, 32: 5

8 Jha N, Mishra A K et al. J Alloy Compd[J], 2001, 329: 224

9 Zeng X Q, Wang Q D, Lü Y Z et al. Materials Science and Engineering[J], 2001, A301: 154

10 Huang X F, Zhou H, He Z M et al. J Rare Earth[J], 2003, 21: 73

\title{
Ce 元素的添加对 Mg-1.2Ca 合金氧化行为和表面张力的影响
}

\author{
秦 林, 丁 俭, 赵维民, 方 正 \\ (河北工业大学, 天津 300132)
}

\begin{abstract}
摘 要: 为了发展高性能阻燃镁合金, 对工业纯镁在添加元素 $\mathrm{Ca}$ 和 $\mathrm{Ce}$ 的氧化性能进行了研究。结果表明, 随着 $\mathrm{Ce}$ 含量从 $0 \%$ 到 $1.5 \%$ (质 量分数) 的增加, $\mathrm{Mg}-1.2 \mathrm{Ca}$ 合金的燃点不断提高, 熔体表面张力不断下降。 $\mathrm{Mg}-1.2 \mathrm{Ca}-1.2 \mathrm{Ce}$ 燃点可以达到 $780{ }^{\circ} \mathrm{C}$, 而且可在大气中不添加任 何保护的情况下进行熔炼。随着 $\mathrm{Ce}$ 含量的增加, $\mathrm{Mg}-1.2 \mathrm{Ca}$ 熔体氧化膜变得光滑而致密, 可以很好地起到阻止氧化、燃烧的效果。通过检测 和分析, $\mathrm{Mg}-1.2 \mathrm{Ca}-1.2 \mathrm{Ce}$ 的氧化膜可以分成 3 层: 外层是疏松的 $\mathrm{MgO}$, 中间层是 $\mathrm{MgO}-\mathrm{CaO}$ 复合氧化膜, 内层是 $\mathrm{MgO}_{\mathrm{g}}-\mathrm{Ce}_{2} \mathrm{O}_{3}$ 复合氧化膜。 关键词: 镁合金; 氧化; 表面张力; 钻; 铈
\end{abstract}

作者简介: 秦 林, 男, 1988 年生, 硕士, 河北工业大学材料科学与工程学院, 天津 300132, E-mail: qlin_hbut@163.com 